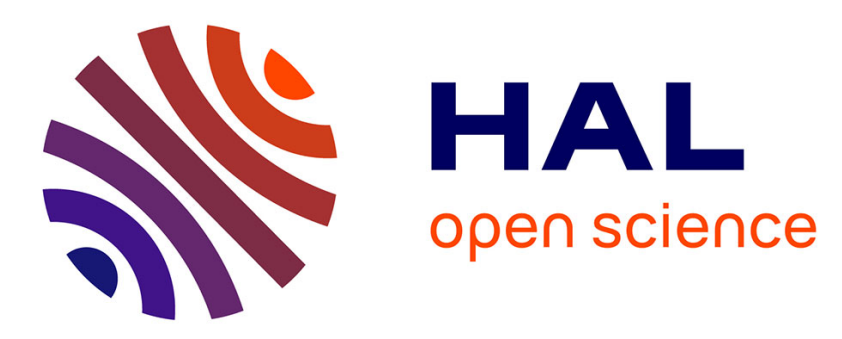

\title{
Tuning the chemical properties of europium complexes as downshifting agents for copper indium gallium selenide solar cells
}

\author{
Anatolie Gavriluta, Thomas Fix, Aline M. Nonat, Abdelilah Slaoui, \\ Jean-Francois Guillemoles, Loïc J. Charbonnière
}

\section{To cite this version:}

Anatolie Gavriluta, Thomas Fix, Aline M. Nonat, Abdelilah Slaoui, Jean-Francois Guillemoles, et al.. Tuning the chemical properties of europium complexes as downshifting agents for copper indium gallium selenide solar cells. Journal of Materials Chemistry A, 2017, 5 (27), pp.14031-14040. 10.1039/C7TA02892J . hal-01972837

\section{HAL Id: hal-01972837 https://hal.science/hal-01972837}

Submitted on 8 Jan 2019

HAL is a multi-disciplinary open access archive for the deposit and dissemination of scientific research documents, whether they are published or not. The documents may come from teaching and research institutions in France or abroad, or from public or private research centers.
L'archive ouverte pluridisciplinaire HAL, est destinée au dépôt et à la diffusion de documents scientifiques de niveau recherche, publiés ou non, émanant des établissements d'enseignement et de recherche français ou étrangers, des laboratoires publics ou privés. 


\section{Tuning the Chemical Properties of Europium Complexes as Downshifting Agents for Copper Indium Gallium Selenide Solar Cells}

\begin{tabular}{|r|l|}
\hline Journal: & Journal of Materials Chemistry A \\
\hline Manuscript ID & TA-ART-04-2017-002892.R1 \\
\hline Article Type: & Paper \\
\hline Date Submitted by the Author: & $25-$ May-2017 \\
\hline Complete List of Authors: & $\begin{array}{l}\text { Gavriluta, Anatolie; Institut Photovoltaïque d'Ile de France (IPVF); ICube } \\
\text { Laboratory, Université de Strasbourg and CNRS; LIMAA, IPHC, UMR 7178 } \\
\text { CNRS, Université de Strasbourg, ECPM } \\
\text { Fix, Thomas; ICube Laboratory, Université de Strasbourg and CNRS } \\
\text { Nonat, Aline; CNRS, IPHC (UMR7578), DSA, LIMAA } \\
\text { SLAOUI, Abdelilah; ICUBE, } \\
\text { Guillemoles, Jean Francois; CNRS-EDF } \\
\text { Charbonnière, Loïc; LIMAA, IPHC, UMR 7178 CNRS, Université de } \\
\text { Strasbourg, ECPM }\end{array}$ \\
\hline
\end{tabular}




\title{
Journal of Materials Chemistry A
}

\section{PAPER}

Received 00th January 20xx, Accepted 00th January 20xx

DOI: $10.1039 / x 0 x \times 00000 x$

www.rsc.org/

\section{Tuning the Chemical Properties of Europium Complexes as Downshifting Agents for Copper Indium Gallium Selenide Solar Cells}

\author{
Anatolie Gavriluta, ${ }^{\mathrm{a}, \mathrm{b}, \mathrm{c}, *}$ Thomas Fix, ${ }^{\mathrm{b}, *}$ Aline Nonat, ${ }^{\mathrm{c}, *}$ Abdelilah Slaoui, ${ }^{\mathrm{b}}$ Jean-François \\ Guillemoles, $^{d, a}$ Loïc J. Charbonnière ${ }^{c}$
}

\begin{abstract}
New europium(III) $\beta$-diketonate based complexes with the general formula $\left[\mathrm{Eu}(\boldsymbol{\beta} \text {-Dik })_{3}(\mathbf{N L})_{x}\right]$, where $\boldsymbol{\beta}$-Dik $=2$ thenoyltrifluoroacetonate, 4,4,4-trifluoro-1-phenyl-1,3-butanedione, 4,4,4-trifluoro-1-(2-naphthyl)-1,3-butanedione, NL = diphenyl sulfoxide $(x=2)$, bis[2-(diphenylphosphino)phenyl] ether oxide $(x=1)$, triphenylphosphine oxide $(x=2), 5,6$ epoxy-5,6-dihydro-[1,10]phenanthroline $(x=1)$, are designed and synthesized. The coordination complexes are comprehensively characterized by elemental analysis, infrared and ${ }^{1} \mathrm{H},{ }^{13} \mathrm{C},{ }^{19} \mathrm{~F} N \mathrm{NMR}$ spectroscopy. The complexes are embedded into poly(ethylene-co-vinyl acetate) (EVA), poly(methyl methacrylate) (PMMA) or poly(vinyl butyral-co-vinyl alcohol-co-vinyl acetate) (PVB) matrices. Photoluminescence behavior is investigated in detail and exhibits the characteristic ${ }^{5} \mathrm{D}_{0} \rightarrow{ }^{7} \mathrm{~F}_{0-4}$ emission bands with quantum yields of 55-83 \% in the solid state and 34-86 \% in the polymers. Encapsulation of CIGS solar cells with luminescent downshifting (LDS) layer results in an important improvement of external quantum efficiency (EQE) in the UV region, from $14 \%$ and up to $58 \%$ at $360 \mathrm{~nm}$ for the best compound. The short circuit current density $\left(\mathrm{J}_{\mathrm{sc}}\right)$ in the range of $300-400 \mathrm{~nm}$ increases up to $0.77 \mathrm{~mA} / \mathrm{cm}^{2}$ for the best LDS which corresponds to $71 \%$ of the $J_{s c}$ enhancement of an ideal downshifter. I-V measurements follow the spectral response data with an absolute

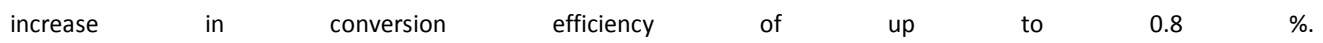

\section{Introduction}

Efficient management of sunlight photons is a fundamental issue in photovoltaics (PV). Today semiconductors used in PV do not convert effectively all the photons above the bandgap energy and, as a result, they mismatch with the incident solar spectrum. The combination of different materials and optical phenomena to better match the solar irradiance spectrum, and the conversion of the sunlight spectrum to better fit the semiconductor capabilities are the main strategies to improve solar cell conversion efficiency. ${ }^{1}$ Two spectral windows are used inefficiently in many single junction PV devices and solar cells such as CIGS (Figure 1): ${ }^{2}$ the $300-500 \mathrm{~nm}$ region which accounts for $18.5 \%$ of the power (or $9.4 \%$ of the photons) and the $4000-1200 \mathrm{~nm}$ which represents $16 \%$ of the power (or 33 $\%$ of the photon energy). One of the most efficient way to enhance the cell performance without modifying the solar cell

\footnotetext{
a. Institut Photovoltaïque d'lle de France (IPVF), 8 rue de la Renaissance, 92160 Antony, France. E-mail: gavriluta.anatolie@gmail.com

${ }^{b}$ ICube Laboratory, Université de Strasbourg and CNRS, 23 rue du Loess BP 20 CR, 67037 Strasbourg Cedex 2, France.E-mail:thomas.fix@unistra.fr

c. LIMAA, IPHC, UMR 7178 CNRS, Université de Strasbourg, ECPM, 25 rue Becquerel, 67087 Strasbourg Cedex, France. E-mail:aline.nonat@unistra.fr

d. EDF R\&D, IRDEP, Institute of R\&D on Photovoltaic Energy, UMR 7174, CNRS-EDFChimie ParisTech, 6 Quai Watier-BP 49, 78401 Chatou Cedex, France

† Electronic Supplementary Information (ESI) available: [NMR, Infrared, Excitation, Emission, Photoluminescence decay, Transmittance and Spectral response spectra of compounds]. See DOI: 10.1039/x0xx00000x
}

absorber is to use a photon conversion approach such as downshifting (DS, an UV photon converted into a Vis or NIR photon), downconversion (DC, an UV photon converted into two Vis or NIR photons) and upconversion (UC, two IR photons converted into one Vis or near NIR photon). ${ }^{3,4}$ These strategies are part of the next-generation advanced concepts. ${ }^{5}$

\section{(Figure 1)}

Until now, research efforts on DC and UC materials have mostly focused on lanthanide(III) phosphors, which applications as photon converters in solar cells are limited by the narrowband and inefficient absorption of $\operatorname{Ln}(\mathrm{III})$ ions and by their low quantum yields (QY) in the NIR. ${ }^{6-8}$ In contrast, DS materials such as quantum dots, ${ }^{9,10}$ transition metal phosphors, ${ }^{11-14}$ organic dyes ${ }^{15-17}$ and rare earth coordination complexes $^{18-22}$ have already displayed encouraging improvements in solar cell performance. Among these compounds, two kinds of DS materials are in strong competition: organic dyes with QY approaching unity and $\mathrm{Eu}$ (III) coordination complexes with QYs of 80-90\%. Advantageously, the latter display large pseudo-Stokes' shifts without self-absorption, and show ${ }^{5} D_{0} \rightarrow^{7} F_{J}(J=0-6)$ narrow emission bands, whose ${ }^{5} D_{0} \rightarrow{ }^{7} F_{2}$ transition at $c a 613 \mathrm{~nm}$ transition reaches up to $80-90 \%$ of all emission light and milliseconds photoluminescence (PL) lifetime. ${ }^{23}$ The long term stability upon light irradiation and high thermal decomposition 
temperature of Eu(III) complexes have been partly demonstrated while testing their application to electroluminescence. ${ }^{24}$

Within many different classes of europium(III) coordination complexes, the tris( $\beta$-diketonate) ternary complexes appear to be suitable compounds to meet the requirements for DS. ${ }^{25-29}$ Nevertheless, significant improvements can still be achieved by shifting the excitation window towards longer wavelengths and therefore optimizing the spectral window 'eligible' to photon conversion as well as by improving their PL QY. ${ }^{25-32}$ In this respect, previous studies on the $\mathrm{Eu}(\mathrm{III})$ complexes such as: $\left[\mathrm{Eu}(\mathrm{TTA})_{3}(\mathrm{DBSO})_{2}\right](\mathrm{TTA}=2$-thenoyltrifluoroacetonate, $\mathrm{DBSO}=$ diphenyl sulfoxide), $\left[\mathrm{Eu}(\mathrm{TTA})_{3}(\mathrm{TPPO})_{2}\right]$ (TPPO= triphenylphosphine oxide), $\left[\mathrm{Eu}(\mathrm{TTA})_{3}(\mathrm{DPEPO})\right](\mathrm{DPEPO}=\mathrm{bis}[2$ (diphenylphosphino)phenyl] ether oxide), [Eu(TTA) $\left.{ }_{3}(E P h e n)\right]$ EPhen = 5,6-epoxy-5,6-dihydro-[1,10]phenanthroline) and $\left[\mathrm{Eu}(\mathrm{NTA})_{3}(\mathrm{DMSO})_{2}\right]$ (NTA = 4,4,4-trifluoro-1-(2-naphthyl)-1,3butanedione, $\mathrm{DMSO}=$ dimethyl sulfoxide) have demonstrated that promoting synergistic interaction of singlet and triplet excited-states of $\beta$-diketone and neutral ligands can influence the absorbance, ligand-to-metal sensitization efficiency and finally the luminescence $Q Y .^{32-37}$

This work reports on the design and synthesis of 10 europium(III) complexes with the general formula $[\mathrm{Eu}(\boldsymbol{\beta}$ Dik) ${ }_{3}(\mathbf{N L})_{x}$ ] (where $\boldsymbol{\beta}$-Dik $=$ TTA, NTA, 4,4,4-trifluoro-1-phenyl1,3-butanedione (PTA), NL = DBSO $(x=2)$, TPPO $(x=2)$, DPEPO $(x=1)$, EPhen $(x=1))$, where 8 of which being newly synthesized and fully characterized apart from $\left[\mathrm{Eu}(\mathrm{TTA})_{3}(\mathrm{DPEPO})\right]$ and $\left[\mathrm{Eu}(\mathrm{TTA})_{3}(\text { Ephen })\right]^{32,34}$ Their spectroscopic features as well as photo-physical properties in solid state and embedded into poly(ethylene-co-vinyl acetate) (EVA), poly(methyl methacrylate) (PMMA) and poly(vinyl butyral-co-vinyl alcohol-co-vinyl acetate) (PVB) have been studied. Finally their influence on the CIGS solar cell performances such as reflectance, spectral response (SR) and I$\checkmark$ characteristics is evaluated.

\section{Experimental section}

\section{Materials}

$\mathrm{EuCl}_{3} \cdot 6 \mathrm{H}_{2} \mathrm{O}$ (99.99\%), 2-thenoyltrifluoroacetone (99\%), 4,4,4trifluoro-1-(2-naphthyl)-1,3-butanedione (99 \%), 4,4,4trifluoro-1-phenyl-1,3-butanedione (99\%), triphenylphosphine oxide (98\%), diphenyl sulfoxide (96 \%), bis[2(diphenylphosphino)phenyl] ether oxide (98\%), 5,6-epoxy-5,6dihydro-[1,10]phenanthroline (98\%), poly(ethylene-co-vinyl acetate) (EVA, 33 wt. \% vinyl acetate), poly(methyl methacrylate) (PMMA, average $\mathrm{M}_{\mathrm{w}} \sim 120,000$ ), poly(vinyl butyral-co-vinyl alcohol-co-vinyl acetate) (PVB, average $\mathrm{Mw} \sim$ $90,000-120,000)$ and all solvents were purchased from SigmaAldrich.

\section{General protocol synthesis}

To a solution of a $\beta$-diketone ( $\beta$-Dik) $(1.2 \mathrm{mmol})$ and a neutral ligand (NL) $(0.82 \mathrm{mmol}$ for monodentate and $0.41 \mathrm{mmol}$ for bidentate ligand) in $10 \mathrm{~mL}$ of ethanol, aqueous $\mathrm{NaOH}$ solution
(1.2 mL, $1 \mathrm{~mol} / \mathrm{L}, 1.2 \mathrm{mmol}$ ) was added dropwise. The mixture was heated at $70-75^{\circ} \mathrm{C}$ for $5 \mathrm{~min}$ and a solution of $\mathrm{EuCl}_{3}$ (146 $\mathrm{mg}$ of $\mathrm{EuCl}_{3} \cdot 6 \mathrm{H}_{2} \mathrm{O}$ in $3 \mathrm{~mL}$ of water, $0.4 \mathrm{mmol}$ ) was added dropwise. A white precipitate of $\left[\mathrm{Eu}(\boldsymbol{\beta}-\mathrm{Dik})_{3}(\mathbf{N L})_{2}\right]$ was forming during the addition of the $\mathrm{EuCl}_{3}$ solution. The hot suspension was agitated and cooled to ambient temperature (in $1 \mathrm{~h}$ ). It was filtered off, washed with ethanol (50\%) $(2 \times 3 \mathrm{~mL})$ and dried in vacuo.

1: $\left[\mathrm{Eu}(\mathrm{TTA})_{3}(\mathrm{DBSO})_{2}\right.$ ]. Yield: $0.35 \mathrm{~g}, 72 \%{ }^{1} \mathrm{H}$ NMR $(400.130$ $\left.\mathrm{MHz}, \mathrm{CDCl}_{3}, \delta\right): 1.64\left(\mathrm{~s}, 3 \mathrm{H}, \mathrm{H}_{3}\right), 5.76\left(\mathrm{~s}, 3 \mathrm{H}, \mathrm{H}_{6}\right), 6.37(\mathrm{t}, J=4.2$ $\left.\mathrm{Hz}, 3 \mathrm{H}, \mathrm{H}_{7}\right), 6.81\left(\mathrm{~d}, J=5.0 \mathrm{~Hz}, 3 \mathrm{H}, \mathrm{H}_{8}\right), 8.04\left(\mathrm{t}, J=7.4 \mathrm{~Hz}, 4 \mathrm{H}_{\mathrm{p}-\mathrm{ph}}\right.$ DBSO), 8.13 ( $\left.\mathrm{t}, J=7.4 \mathrm{~Hz}, 8 \mathrm{H}_{\mathrm{m}-\mathrm{ph} \text { DBSO}}\right), 11.61\left(\mathrm{~d}, J=5.3 \mathrm{~Hz}, 8 \mathrm{H}_{\mathrm{o}-\mathrm{ph}}\right.$ DBSO); $\left.{ }^{19} \mathrm{~F} \mathrm{NMR} \mathrm{(376.498} \mathrm{MHz,} \mathrm{CDCl}_{3}, \delta\right):-80.84$ (s, 9F); ${ }^{13} \mathrm{C} \mathrm{NMR}$ $\left(100.613 \mathrm{MHz}, \mathrm{CDCl}_{3}, \delta\right)$ : 53.29, 95.60, 123.53, 126.63, 128.48, 130.76, 132.45, 134.14, 147.09, 166.16; IR, v, cm $\mathrm{cm}^{-1}$ : 427, 460, $479,536,578,604,640,681,716,741,767,782,858,933$, $994,1011,1030,1060,1088,1128,1180,1228,1243,1287$, $1298,1354,1411,1445,1470,1500,1519,1534,1599$, $1629,2901,2923,2968,2988,3000,3061$; Anal. calcd. for $\mathrm{C}_{48} \mathrm{H}_{32} \mathrm{EuF}_{9} \mathrm{O}_{8} \mathrm{~S}_{5}\left(M_{r}=1219.98 \mathrm{~g} / \mathrm{mol}\right): \mathrm{C} 47.26, \mathrm{H}$ 2.64; found: C 46.92, H 2.66.

2: $\left[\mathrm{Eu}(\mathrm{TTA})_{3}\right.$ (DPEPO)]. Yield: $0.47 \mathrm{~g}, 85 \% .{ }^{1} \mathrm{H}$ NMR $(400.130$ $\left.\mathrm{MHz}, \mathrm{CDCl}_{3}, \delta\right): 4.18\left(\mathrm{~s}, 3 \mathrm{H}, \mathrm{H}_{3}\right), 6.66\left(\mathrm{t}, J=3.8 \mathrm{~Hz}, 3 \mathrm{H}, \mathrm{H}_{7}\right), 6.86$ $\left(\mathrm{d}, J=2.3 \mathrm{~Hz}, 3 \mathrm{H}, \mathrm{H}_{6}\right), 6.93\left(\mathrm{~d}, J=4.6 \mathrm{~Hz}, 3 \mathrm{H}, \mathrm{H}_{8}\right), 7.12-7.26(\mathrm{~m}$, $\left.6 \mathrm{H}_{\text {DPEPO }}\right), 7.44-7.58\left(\mathrm{~m}, 10 \mathrm{H}_{\text {DPEPO }}\right), 7.64-7.74\left(\mathrm{~m}, 4 \mathrm{H}_{\text {DPEPO }}\right), 8.92$ $\left(\mathrm{m}, 8 \mathrm{H}_{\text {DPEPO }}\right) ;{ }^{19} \mathrm{~F} \mathrm{NMR}\left(376.498 \mathrm{MHz}, \mathrm{CDCl}_{3}, \delta\right):-77.3(\mathrm{~s}, 6 \mathrm{~F}) ;{ }^{13} \mathrm{C}$ NMR $\left(100.613 \mathrm{MHz}, \mathrm{CDCl}_{3}, \delta\right): 96.5,120.37,123.47,124.14$, $126.25,128.55,132.16,132.33,132.64,133.0,133.65,134.55$, $135.08,148.97,160.02,164.8 ; \mathrm{IR}, \mathrm{v}, \mathrm{cm}^{-1}: 421,437,458,470$, $486,511,542,579,605,641,679,692,712,724,732,746$, $762,783,809,860,872,909,934,960,982,998,1013,1029$, $1061,1075,1105,1123,1169,1229,1244,1262,1297,1352$, $1414,1437,1466,1500,1520,1535,1567,1604,1632,2901$, 2973, 2988, 3058; Anal. calcd. for $\mathrm{C}_{60} \mathrm{H}_{40} \mathrm{EuF}_{9} \mathrm{O}_{9} \mathrm{P}_{2} \mathrm{~S}_{3}\left(M_{r}=\right.$ $1386.05 \mathrm{~g} / \mathrm{mol}$ ): C 51.99, H 2.91; found: C 51.94, H 2.91.

3: [Eu(TTA) ${ }_{3}$ (EPhen)]. Yield: $0.36 \mathrm{~g}, 90 \% .{ }^{1} \mathrm{H}$ NMR $(400.130$ $\left.\mathrm{MHz}_{\mathrm{CDCl}}, \delta\right): 2.91\left(\mathrm{~s}, 3 \mathrm{H}, \mathrm{H}_{3}\right), 6.14\left(\mathrm{~s}, 3 \mathrm{H}, \mathrm{H}_{6}\right), 6.50(\mathrm{~s}, 3 \mathrm{H}$, $\left.\mathrm{H}_{7}\right), 6.57\left(\mathrm{~s}, 2 \mathrm{H}_{5,6(\text { Ephen })}\right), 6.97\left(\mathrm{~d}, J=4.0 \mathrm{~Hz}, 3 \mathrm{H}, \mathrm{H}_{8}\right), 8.61$ (d, $J=$

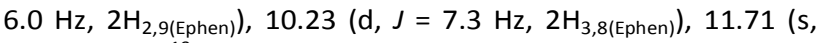

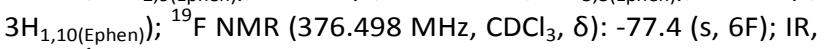
$\mathrm{V}, \mathrm{cm}^{-1}: 412,433,461,495,520,542,580,604,622,641,683$, $714,747,768,788,802,810,860,896,910,933,956,987$, $1026,1036,1063,1083,1132,1139,1184,1203,1231,1249$, $1291,1307,1355,1393,1412,1436,1463,1477,1506,1539$, $1578,1596,1626,2901,2972,2988$, 3089; Anal. calcd. for $\mathrm{C}_{36} \mathrm{H}_{20} \mathrm{EuF}_{9} \mathrm{~N}_{2} \mathrm{O}_{7} \mathrm{~S}_{3}\left(M_{r}=1011.69 \mathrm{~g} / \mathrm{mol}\right): \mathrm{C} 42.74, \mathrm{H} 1.99, \mathrm{~N}$ 2.77; found: C 42.47, H 1.99, N 2.57.

4: [Eu(PTA $)_{3}(\text { TPPO })_{2}$ ]. Yield: $0.46 \mathrm{~g}, 85 \%$ \% ${ }^{1} \mathrm{H}$ NMR $(400.130$ $\left.\mathrm{MHz}_{\mathrm{CDCl}}, \delta\right): 3.00\left(\mathrm{~s}, 3 \mathrm{H}, \mathrm{H}_{3}\right), 6.57\left(\mathrm{~s}, 6 \mathrm{H}, \mathrm{H}_{7,9}\right), 6.95(\mathrm{~m}, 9 \mathrm{H}$, $\left.\mathrm{H}_{8,6,10}\right), 7.73-7.83\left(\mathrm{~m}, 18 \mathrm{H}_{\text {TPPO }}\right), 10.86$ (broad, $\left.12 \mathrm{H}_{\text {TPPO }}\right) ;{ }^{19} \mathrm{~F} \mathrm{NMR}$ (376.498 MHz, $\left.\mathrm{CDCl}_{3}, \delta\right):-79.93(\mathrm{~s}, 6 \mathrm{~F}) ;{ }^{13} \mathrm{C} \mathrm{NMR}(100.613 \mathrm{MHz}$, $\left.\mathrm{CDCl}_{3}, \delta\right): 58.02,97.87,125.09,125.92,129.61,129.74,132.42$, $132.99,135.69,135.80,138.88,139.98,154.91,155.18$, 173.47; IR, v, cm $\mathrm{cm}^{-1}: 409,443,460,511,536,579,631,692$, $723,744,758,792,809,844,942,979,999,1025,1073,1095$, $1120,1137,1169,1238,1281,1316,1437,1480,1489,1518$, $1533,1579,1598,1614,1625,2902,2972,2988,3060$; Anal. 
calcd. for $\mathrm{C}_{66} \mathrm{H}_{48} \mathrm{EuF}_{9} \mathrm{O}_{8} \mathrm{P}_{2}\left(M_{r}=1354.0 \mathrm{~g} / \mathrm{mol}\right)$ : C 58.55, H 3.57; found: $\mathrm{C}$ 58.18, $\mathrm{H}$ 3.57.

5: [Eu(PTA $)_{3}(\text { DBSO })_{2}$ ]. Yield: 0.31 g, $65 \%$ \% ${ }^{1} \mathrm{H}$ NMR $(400.130$ $\left.\mathrm{MHz}_{\mathrm{CDCl}}, \delta\right): 1.59\left(\mathrm{~s}, 3 \mathrm{H}, \mathrm{H}_{3}\right), 6.58\left(\mathrm{~s}, 6 \mathrm{H}, \mathrm{H}_{7,9}\right), 7.02(\mathrm{~m}, 9 \mathrm{H}$, $\left.\mathrm{H}_{8,6,10}\right), 7.99$ (t, $\left.J=7.3 \mathrm{~Hz}, 4 \mathrm{H}_{\mathrm{p}-\mathrm{ph} \mathrm{DBSO}}\right), 8.06\left(\mathrm{t}, J=7.4 \mathrm{~Hz}, 8 \mathrm{H}_{\mathrm{m}-\mathrm{ph}}\right.$

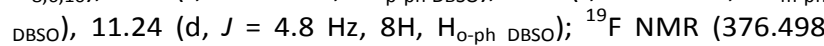
$\left.\mathrm{MHz}, \mathrm{CDCl}_{3}, \delta\right):-80.69$ (s, 6F); ${ }^{13} \mathrm{C}$ NMR $\left(100.613 \mathrm{MHz} \mathrm{CDCl}_{3}\right.$, ठ): $53.31,94.06,125.12,126.01,128.28,130.74,132.46$, 133.27, 147.52, 174,55; IR, v, cm ${ }^{-1}: 428,477,507,537,578$, $630,684,693,716,741,761,794,809,943,994,1011,1076$, $1090,1129,1159,1180,1239,1285,1317,1444,1472,1488$, 1534, 1575, 1598, 1611, 1638, 2973, 3000, 3025, 3062; Anal. calcd. for $\mathrm{C}_{54} \mathrm{H}_{38} \mathrm{EuF}_{9} \mathrm{O}_{8} \mathrm{~S}_{2}\left(M_{r}=1201.96 \mathrm{~g} / \mathrm{mol}\right): \mathrm{C} 53.96, \mathrm{H}$ 3.19; found: C 53.44, H 3.19.

6: [Eu(PTA) $)_{3}$ (DPEPO)]. Yield: 0.49 g, $90 \%$ \% ${ }^{1} \mathrm{H}$ NMR $(400.130$ $\left.\mathrm{MHz}, \mathrm{CDCl}_{3}, \delta\right): 4.71\left(\mathrm{~s}, 3 \mathrm{H}, \mathrm{H}_{3}\right), 7.0-7.3\left(\mathrm{~m}, 21 \mathrm{H}, 15 \mathrm{H}_{\mathrm{ph}}+\right.$ $\left.6 \mathrm{H}_{\text {DPEPO }}\right), 7.43\left(\mathrm{~m}, 6 \mathrm{H}_{\text {DPEPO }}\right), 7.65\left(\mathrm{~m}, 8 \mathrm{H}_{\text {DPEPO }}\right), 8.63$ (broad, $4 \mathrm{H}_{\text {DPEPO }}$ ), 8.76 (broad, $\left.4 \mathrm{H}, \mathrm{H}_{\text {DPEPO }}\right) ;{ }^{19} \mathrm{~F}$ NMR $(376.498 \mathrm{MHz}$, $\left.\mathrm{CDCl}_{3}, \delta\right)$ : -76.71 (s, 6F); ${ }^{13} \mathrm{C}$ NMR $\left(100.613 \mathrm{MHz}, \mathrm{CDCl}_{3}, \delta\right)$ : 53.58, 101.30, 119.91, 119.98, 123.67, 123.84, 125.50, 126.56, $128.73-129.17,131.97,132.27,132.62,134.20,134.62$, 135.44, 147.20, 162.43, 176.48; IR, v, $\mathrm{cm}^{-1}: 443,459,472,484$, 517, 542, 578, 629, 670, 692, 703, 715, 734, 744, 762, 794, $809,848,864,875,931,944,961,976,1000,1026,1077$, $1106,1136,1169,1205,1235,1262,1288,1307,1317,1373$, $1436,1468,1523,1537,1578,1598,1615,1622,1640,2967$, 2992, 3028, 3060; Anal. calcd. for $\mathrm{C}_{54} \mathrm{H}_{38} \mathrm{EuF}_{9} \mathrm{O}_{8} \mathrm{P}_{2}\left(M_{r}=\right.$ $1367.98 \mathrm{~g} / \mathrm{mol}$ ): C 57.95, H 3.39; found: C 57.88, H 3.40.

7: [Eu(PTA $)_{3}$ (EPhen)]. Yield: $0.32 \mathrm{~g}, 80 \% .{ }^{1} \mathrm{H}$ NMR $(400.130$ $\left.\mathrm{MHz}, \mathrm{CDCl}_{3}, \delta\right): 3.10\left(\mathrm{~s}, 3 \mathrm{H}, \mathrm{H}_{3}\right), 6.81\left(\mathrm{~s}, 2 \mathrm{H}_{5,6(\text { Ephen })}\right), 7.14(\mathrm{t}, J=$ $\left.7.1 \mathrm{~Hz}, 3 \mathrm{H}, \mathrm{H}_{8}\right), 7.29-7.40\left(\mathrm{~m}, 12 \mathrm{H}, \mathrm{H}_{6,7,9,10}\right), 8.55(\mathrm{~d}, J=7.2 \mathrm{~Hz}$, $\left.2 \mathrm{H}_{2,9(\text { Ephen })}\right), 10.40$ (d, J = $\left.7.5 \mathrm{~Hz}, 2 \mathrm{H}_{3,8(\text { Ephen })}\right), 10.84$ (s,

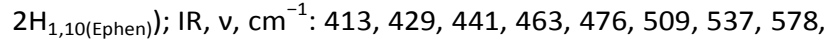
$629,640,682,699,718,744,764,796,808,829,856,893$, $942,957,965,1001,1019,1074,1128,1177,1218,1240$, $1285,1309,1317,1375,1388,1434,1466,1488,1527,1571$, $1595,1604,1618,1630,2851,2926,3060$; Anal. calcd. for $\mathrm{C}_{42} \mathrm{H}_{26} \mathrm{EuF}_{9} \mathrm{O}_{7} \mathrm{~N}_{2}\left(M_{r}=993.63 \mathrm{~g} / \mathrm{mol}\right): \mathrm{C} 50.77, \mathrm{H} 2.64$; found: $\mathrm{C}$ 50.68, H 2.75.

8: [Eu(NTA $)_{3}(\text { TPPO })_{2}$ ]. Yield: $0.52 \mathrm{~g}, 87 \% .{ }^{1} \mathrm{H}$ NMR $(400.130$ $\left.\mathrm{MHz}, \mathrm{CDCl}_{3}, \delta\right): 2.83\left(\mathrm{~s}, 3 \mathrm{H}, \mathrm{H}_{3}\right), 6.85\left(\mathrm{~s}, 3 \mathrm{H}, \mathrm{H}_{6}\right), 7.24(\mathrm{~s}, 3 \mathrm{H}$, $\left.\mathrm{H}_{14}\right), 7.34\left(\mathrm{t}, J=7.3 \mathrm{~Hz}, 3 \mathrm{H}, \mathrm{H}_{9}\right), 7.41\left(\mathrm{t}, J=7.3 \mathrm{~Hz}, 3 \mathrm{H}, \mathrm{H}_{10}\right), 7.50$ $\left(\mathrm{m}, 6 \mathrm{H}, \mathrm{H}_{11,13}\right), 7.7-7.8\left(\mathrm{~m}, 21 \mathrm{H}, 3 \mathrm{H}_{8}+18 \mathrm{H}_{\text {TPPO }}\right), 10.87$ (broad, $\left.12 \mathrm{H}_{\text {TPPO }}\right) ;{ }^{19} \mathrm{~F} \mathrm{NMR}\left(376.498 \mathrm{MHz}, \mathrm{CDCl}_{3}, \delta\right):-79.79(\mathrm{~s}, 6 \mathrm{~F}) ;{ }^{13} \mathrm{C}$ NMR $\left(100.613 \mathrm{MHz}, \mathrm{CDCl}_{3}, \delta\right): 122.29,125.19,125.43,126.75$, $127.48,128.33,129.59-129.82,133.12,135.6-136.1$; IR, v, $\mathrm{cm}^{-1}: 407,454,471,520,537,567,683,692,722,746,766$, $788,865,936,959,998,1028,1072,1095,1120,1170,1226$, $1249,1289,1438,1463,1472,1508,1527,1571,1594,1614$, 1642, 2849, 2924, 3058; Anal. calcd. for $\mathrm{C}_{78} \mathrm{H}_{54} \mathrm{EuF}_{9} \mathrm{O}_{8} \mathrm{P}_{2} \cdot 0.75 \mathrm{H}_{2} \mathrm{O}\left(M_{r}=1517.67 \mathrm{~g} / \mathrm{mol}\right): \mathrm{C} 61.72, \mathrm{H}$ 3.69; found: $\mathrm{C} 61.72, \mathrm{H} 3.72$.

9: [Eu(NTA) ${ }_{3}$ (DPEPO)]. Yield: 0.49 g, $81 \%$ \% ${ }^{1} \mathrm{H}$ NMR $(400.130$ $\left.\mathrm{MHz}, \mathrm{CDCl}_{3}, \delta\right): 5.10\left(\mathrm{~s}, 3 \mathrm{H}, \mathrm{H}_{3}\right), 7.14\left(\mathrm{~m}, 6 \mathrm{H}_{\text {DPEPO }}\right), 7.35-7.65$ $\left(\mathrm{m}, 32 \mathrm{H}, 18 \mathrm{H}_{6,9,11,10,13,14}+14 \mathrm{H}_{\text {DPEPO }}\right), 7.80\left(\mathrm{~m}, 3 \mathrm{H}, \mathrm{H}_{8}\right) 8.71$ (broad, $4 \mathrm{H}_{\text {DPEPO }}$ ), 8.91 (broad, $\left.4 \mathrm{H}_{\text {DPEPO}}\right) ;{ }^{19} \mathrm{~F} \mathrm{NMR}(376.498 \mathrm{MHz}$, $\left.\mathrm{CDCl}_{3}, \delta\right)$ : -79.09 (s, 6F); ${ }^{13} \mathrm{C}$ NMR $\left(100.613 \mathrm{MHz}, \mathrm{CDCl}_{3}, \delta\right)$ :
$64.75,98.59,119.66,119.42,123.22,123.58,123.71,125.26$, $125.42,126.91,127.56,127.67,128.79-129.16,129.79$, $130.40,130.88,131.93,132.26,134.0-134.4,134.50,135.17$, $135.28,135.71,161.89,176.56 ; \mathrm{IR}, \mathrm{v}, \mathrm{cm}^{-1}: 452,471,516,545$, $567,682,692,710,721,747,765,787,864,958,1073,1122$, $1175,1247,1268,1291,1437,1462,1478,1508,1526,1570$, $1595,1614,2993,3025,3057$; Anal. calcd. for $\mathrm{C}_{78} \mathrm{H}_{52} \mathrm{EuF}_{9} \mathrm{O}_{9} \mathrm{P}_{2}$ $\left(M_{r}=1518.16 \mathrm{~g} / \mathrm{mol}\right)$ : C 61.71, H 3.45; found: C 61.68, H 3.45 . 10: [Eu(NTA) ${ }_{3}\left(\right.$ EPhen)]. Yield: $0.38 \mathrm{~g}, 83 \%$. ${ }^{1} \mathrm{H}$ NMR $(400.130$ $\left.\mathrm{MHz} \mathrm{CDCl}_{3}, \delta\right): 3.32\left(\mathrm{~s}, 3 \mathrm{H}, \mathrm{H}_{3}\right), 6.79\left(\mathrm{~s}, 2 \mathrm{H}_{5,6(\text { Ephen })}\right), 7.41$ (t, $J=$ $\left.7.5 \mathrm{~Hz}, 3 \mathrm{H}, \mathrm{H}_{9}\right), 7.49\left(\mathrm{~s}, 3 \mathrm{H}, \mathrm{H}_{6}\right), 7.54\left(\mathrm{t}, J=7.4 \mathrm{~Hz}, 3 \mathrm{H}, \mathrm{H}_{10}\right)$, $7.75\left(\mathrm{~m}, 9 \mathrm{H}, \mathrm{H}_{11,13,14}\right), 7.90\left(\mathrm{~d}, J=8.1 \mathrm{~Hz}, 3 \mathrm{H}, \mathrm{H}_{8}\right), 8.54(\mathrm{~d}, J=$ $\left.7.2 \mathrm{~Hz}, 2 \mathrm{H}_{2,9(\text { Ephen })}\right), 10.40\left(\mathrm{~d}, J=7.5 \mathrm{~Hz}, 2 \mathrm{H}_{3,8(\text { Ephen })}\right.$ ), 10.75 (s,

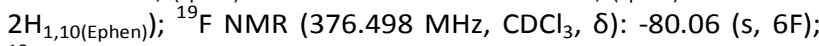
$\left.{ }^{13} \mathrm{C} \mathrm{NMR} \mathrm{(100.613} \mathrm{MHz}, \mathrm{CDCl}_{3}, \delta\right): 56.20,70.82,91.92,122.70$, $125.60,125.68,126.81,128.75,128.92,129.59,130.18$, 136.67, 152.27; IR, v, cm ${ }^{-1}: 413,457,471,520,569,621,641$, $683,721,744,766,792,822,867,894,936,959,1024,1058$, $1074,1134,1187,1196,1218,1227,1251,1295,1353,1436$, 1462, 1478, 1509, 1531, 1569, 1592, 1608, 2903, 2963, 3019, 3061; Anal. calcd. for $\mathrm{C}_{54} \mathrm{H}_{32} \mathrm{EuF}_{9} \mathrm{O}_{7} \mathrm{~N}_{2}\left(M_{r}=1143.81 \mathrm{~g} / \mathrm{mol}\right): \mathrm{C}$ 56.70, H 2.82; found: C 56.68, H 2.82.

\section{Polymeric film preparation}

Procedure A. 2 g of EVA pellets and an appropriate amount of $\left[\mathrm{Eu}(\boldsymbol{\beta} \text {-Dik })_{3}(\mathbf{N L})_{x}\right]$ were dissolved in $50 \mathrm{~mL}$ of a toluene/chloroform mixture (4:1). The concentration of Eu(III) in polymer was $0.3 \mathrm{wt} \%$. A suitable volume of solution (ex. 19 $\mathrm{mL}$ for $100 \pm 10 \mu \mathrm{m}$ thick) was poured in a $10 \mathrm{~cm}$ diameter Petri dish. After overnight slow evaporation, a transparent film was obtained. The Petri dish with the film was placed for one hour in vacuo at $90{ }^{\circ} \mathrm{C}$. After cooling down to room temperature, the film was taken off, placed on quartz substrate or CIGS cells and cured for another one hour in vacuo at $90^{\circ} \mathrm{C}$.

Procedure B. $0.5 \mathrm{~g}$ of PMMA (0.3 g of PVB) and an appropriate amount of $\left[\mathrm{Eu}(\boldsymbol{\beta}-\mathrm{Dik})_{3}(\mathbf{N L})_{\mathrm{x}}\right]$ were dissolved in $5 \mathrm{~mL}$ of chloroform to obtain a concentration of Eu(III) in polymer of $0.3 \mathrm{wt} \%$. A suitable volume of solution (ex. $0.06 \mathrm{~mL}$ for PMMA and $0.09 \mathrm{~mL}$ for PVB for $A=1 \mathrm{~cm}^{2}$ and $50 \pm 5 \mu \mathrm{m}$ thickness layer) was dropped on CIGS solar cell or quartz to form luminescent polymer film after solvent evaporation.

\section{Physical measurements}

Elemental analyses were performed at the Faculty of Chemistry (by the Analysis Service) of the University of Strasbourg. The ${ }^{1} \mathrm{H},{ }^{13} \mathrm{C}$, and ${ }^{19} \mathrm{~F}$ NMR spectra and ${ }^{13} \mathrm{C}-{ }^{1} \mathrm{H}$ HSQC, and ${ }^{1} \mathrm{H}-{ }^{1} \mathrm{H}$ COSY experiments were recorded on a Bruker Ascend $^{\mathrm{TM}} 400$ spectrometer in $\mathrm{CDCl}_{3}$. Chemical shifts are reported in ppm and residual $\mathrm{CDCl}_{3}$ solvent $\left(7.26 \mathrm{ppm}\left({ }^{1} \mathrm{H}\right)\right.$ and $\left.77.16 \mathrm{ppm}\left({ }^{13} \mathrm{C}\right)\right)$ is used as internal reference. ${ }^{38}$ Transmittance spectra of the films coated on quartz were performed on an UV VIS NIR Lambda 19 Perkin Elmer spectrophotometer using normal incidence. Reflectance measurements were done directly from CIGS cells by using the same UV VIS NIR Lambda 19 Perkin Elmer spectrophotometer fitted with an integrating sphere. Steady state emission and excitation spectra were 
recorded on a Horiba Jobin Yvon Fluorolog 3 spectrometer, using a continuous $450 \mathrm{~W}$ Xe lamp. The measurements in the solid state and in the polymer films were done by using a G8 Integrating Sphere (GMP SA, Switzerland) fitted to the Fluorolog 3 spectrometer. Detection was carried out with a Hamamatsu R928 photomultiplier. All spectra were rectified by using the instrumental functions. When necessary, a $399 \mathrm{~nm}$ cut-off filter was used to eliminate second order artefacts. Phosphorescence lifetimes were performed on the same instrument, working in the phosphorescence mode, and with a Xenon flash lamp as the excitation source. Mono-exponential and multi-exponential emission decay profiles were fitted with Origin 9 integrated into FluorEssence 3.5 software. External quantum efficiency (EQE) spectra were recorded on a setup including a light source (tungsten halogen) and automated filter wheels with sorting filters in appropriate order; 41 filters are employed for the measurements and the current is measured with a Keithley 2400 SourceMeter. The EQE measurement consists of the current ratio produced on the sample solar cell at a given wavelength and the current generated by a certified reference detector at the same wavelength. The EQE measurement accuracy was tested with a secondary certified reference. I-V characteristics were obtained by using an Oriel Solar Simulator in AM1.5G conditions and a Keithley 2450 SourceMeter. The layers thicknesses were measured with a TESA DIGICO $305 \mathrm{MI}$ device. The CIGS solar cells measurements (EQE, I-V) were performed before coating, after coating and after removing the LDS layer. More than 200 solar cells have been used for this study.

\section{Photovoltaic cell}

CIGS-based photovoltaic cells were used..$^{39,40}$ They are composed of a soda-lime glass/Mo/CIGS/CdS/ZnO:i/ZnO:Al stack. The procedure is as follows: $1 \mu \mathrm{m}$ molybdenum layer is deposited by sputtering on soda lime glass, followed by $2 \mu \mathrm{m}$ absorber deposited by a standard three-stage co-evaporation process and then, $50 \mathrm{~nm}$ layer of CdS deposited by chemical bath deposition from thiourea. An intrinsic ZnO layer $(50 \mathrm{~nm})$ and $\mathrm{ZnO}: \mathrm{Al}(400 \mathrm{~nm})$ window layer are deposited by r.f. magnetron sputtering. The samples are then cut into small 1-2 $\mathrm{cm}^{2}$ solar cells and photolithography is used to deposit $\mathrm{Ni} / \mathrm{Al}$ grid contacts.

\section{Results and discussion}

\section{Design and synthesis}

The europium(III) coordination complexes based on $\beta$ diketonates: TTA, PTA, NTA and neutral ligands: DMSO, DBSO, TPPO, DPEPO and EPhen are known to show very high luminescence. ${ }^{24,30-32,41}$ Their ligand triplet state at $20300 \mathrm{~cm}^{-1}$ for TTA, ${ }^{41} 21400 \mathrm{~cm}^{-1}$ (PTA), $19600 \mathrm{~cm}^{-1}$ (NTA), $21000 \mathrm{~cm}^{41}$ (DBSO), ${ }^{35} 25000 \mathrm{~cm}^{-1}$ (TPPO), ${ }^{42} 27600 \mathrm{~cm}^{-1}$ (DPEPO) ${ }^{43}$ and $21978 \mathrm{~cm}^{-1}$ (EPhen) ${ }^{32}$ participate effectively in the energy transfer to $\mathrm{Eu}^{3+}$ via ${ }^{5} \mathrm{D}_{1}\left(18973 \mathrm{~cm}^{-1}\right)$ and/or ${ }^{5} \mathrm{D}_{0}\left(17227 \mathrm{~cm}^{-1}\right)$ levels. ${ }^{23}$ On this basis, novel complexes with the general formula $\left[\mathrm{Eu}(\beta \text {-Diketonate })_{3}(\text { Neutral Ligand })_{1-2}\right]$ were designed in order to obtain very highly luminescent europium(III) complexes and to study the influence of the polymer encapsulant on their photo-physical properties.

The series of compounds $\left.\operatorname{Eu}(\boldsymbol{\beta}-\mathbf{D i k})_{3}(\mathbf{N L})_{\mathrm{x}}\right]$ have been synthesized as shown in Figure $\mathbf{2}$ by following typical one-pot procedure. $^{18,44}$

\section{(Figure 2)}

The synthesis of these coordination complexes was accomplished by adding dropwise a stoichiometric quantity of $\mathrm{EuCl}_{3} \cdot 6 \mathrm{H}_{2} \mathrm{O}$ aqueous solution to a hot $\left(70-75^{\circ} \mathrm{C}\right)$ ethanol solution of sodium $\beta$-diketonate (in situ prepared by deprotonation of the $\beta$-diketone with 1 equiv. of $1 \mathrm{M}$ aqueous solution of $\mathrm{NaOH}$ ) and neutral ligand. The compounds precipitate during the addition of $\mathrm{Eu}^{3+}$ solution and the overall chemical yield of the reactions is within $65-90 \%$. In order to confirm the structure and purity, the europium(III) coordination complexes were characterized by elemental analysis, infrared and ${ }^{1} \mathrm{H},{ }^{13} \mathrm{C}$ and ${ }^{19} \mathrm{~F}$ NMR spectroscopy. The results of the microanalytical analyses for $\mathrm{C}, \mathrm{H}$ and $\mathrm{N}$ fit well with the calculated values for each compound and confirm their purity and general formula.

Infrared spectra of the compounds 1-10 (Figure S34) exhibit strong $\mathrm{C}=\mathrm{O}$ and $\mathrm{C}=\mathrm{C}$ stretching vibrations of the $\beta$-diketonate ring in its enol form in the range of $1590-1635 \mathrm{~cm}^{-1}$ and $1520-$ $1540 \mathrm{~cm}^{-1}$ respectively. The absorption band in the region $1280-1310 \mathrm{~cm}^{-1}$ is assigned to $\mathrm{v}_{\text {as }}\left(\mathrm{CF}_{3}\right)$ vibrational mode. The neutral ligands were recognized by $\mathrm{v}_{\text {as }}(\mathrm{C}=\mathrm{N})$ vibration band in the $1569-1577 \mathrm{~cm}^{-1}$ range for EPhen complexes, by $\mathrm{S}=\mathrm{O}$ stretching band in the $994-1010 \mathrm{~cm}^{-1}$ range for DBSO compounds and in case of TPPO and DPEPO coordination complexes by $\mathrm{P}=\mathrm{O}$ stretching vibration band at around 1170 $\mathrm{cm}^{-1}$. Furthermore, the presence of specific $v(E u-O)$ and $v(E u-$ $N)$ vibration bands in the $460-520 \mathrm{~cm}^{-1}$ range provides good evidence that the metal is coordinated with $\beta$-diketonate and $\mathrm{O} / \mathrm{N}$ neutral ligands. ${ }^{45}$

The paramagnetism of europium(III) compounds caused by it $[X e] f^{6}$ electronic configuration induces some broadening and sometime strong signal shifts in NMR spectra. ${ }^{46}$ Similar to $\left[\mathrm{Eu}(\mathrm{TTA})_{3}(\mathrm{TPPO})_{2}\right.$ ], complexes $\mathbf{1 - 1 0}$ are characterized by sharp 1D NMR spectra $\left({ }^{1} \mathrm{H},{ }^{13} \mathrm{C},{ }^{19} \mathrm{~F}\right)$ at room temperature, which are characteristic of a fast exchange between isomeric forms. Complete assignment of the ${ }^{1} \mathrm{H}$ NMR signals was performed by ${ }^{1} \mathrm{H}-{ }^{1} \mathrm{H}$ COSY (Figures S1-33). The resonance signals of $\mathrm{H}_{3}, \mathrm{H}_{6}, \mathrm{H}_{7}$ and $\mathrm{H}_{8}$ from TTA ligand for $\mathbf{1}, \mathbf{2}$ and $\mathbf{3}$ are observed at 1.64 (1), $4.18(2)$ and 2.91 (3) ppm as singlet, $5.76(1), 6.86(2)$ and 6.14 (3) ppm as doublet, 6.37 (1), 6.66 (2) and 6.50 (3) ppm as triplet and 6.81 (1), 6.93 (2) and 6.97 (3) ppm as doublet respectively. In the case of compounds based on PTA ligand, $\mathrm{H}_{3}$ and phenyl $\mathrm{H}$ are observed at $3.00(4), 1.59$ (5), 4.71 (6) 3.10 (7) ppm as singlets and 6.57-6.95 (4), 6.58-7.02 (5), 7.00-7.30 (6) 7.14-7.40 (7) ppm as respectively. The compounds 8, 9, 10 based on NTA ligand give their $\mathrm{H}_{3}$ and naphthyl $\mathrm{H}$ signals at $2.83(8), 5.10(9), 3.32(10) \mathrm{ppm}$ as singlets and 6.85-7.8 (8), 7.35-7.80 (9), 7.41-7.90 (10) ppm, correspondingly. TTA 
derivatives are also characterized by one singlet at $-78 \pm 2 \mathrm{ppm}$ in their ${ }^{19} \mathrm{~F}$ NMR spectra.

\section{Photoluminescence properties}

The photo-physical properties of the coordination complexes 1-10 have been measured in solid state and embedded in different polymer matrices (EVA, PMMA and PVB). The transmittance spectra of the films of 1-10 embedded into EVA and deposited on quartz (Figure S55) display a transparent zone in the visible and near infrared region $(400-800 \mathrm{~nm})$ and an absorption zone in the UV region. While the UV part of the spectra is dominated by $n-\pi^{*}$ and $\pi-\pi^{*}$ intra- and inter-ligand transitions, ${ }^{32}$ the small absorption in the $400-800 \mathrm{~nm}$ region is caused by optical losses induced by compound dispersion in the polymer. The predominant feature of the absorption part of the spectra is the strong $n-\pi^{*}$ and $\pi-\pi^{*}{ }_{\beta \text {-diketone }}$ transitions in the chelate ring appearing in the $320-360 \mathrm{~nm}$ region and $\pi-$ $\pi^{*}$ neutral ligand transitions from 200 to $300 \mathrm{~nm} .{ }^{41-43,47}$ In the case of EPhen, $\pi-\pi^{*}$ intra- and inter-ligand transitions are also observed above $300 \mathrm{~nm}^{32}$ The $\lambda_{\max }$ of the $\pi-\pi^{*}{ }_{\beta}$-diketone transition in the free ligands is by $320 \pm 2 \mathrm{~nm}$ and in their europium(III) complexes is situated at $341 \pm 2 \mathrm{~nm}$ (TTA), $330 \pm$ $2 \mathrm{~nm}$ (PTA) and $338 \pm 2 \mathrm{~nm}$ (NTA) respectively. This bathochromic effect is typical for $\beta$-diketonate metal complexes and is due to the complexation of the enol tautomer. ${ }^{41-43}$ Moreover, the absorption and excitation spectra can be shifted to lower energy (up to $35-40 \mathrm{~nm}$ ) in the solid state or at high complex concentration in the polymer, as shown in Figure $\mathbf{3}$ for complex $\mathbf{2}$ as an example (see Figures S35-S54 for other complexes).

\section{(Figure 3)}

In general, good correlations were observed between the excitation spectra of the compounds in the solid state and embedded into EVA, PMMA and PVB polymer matrices. The small shift of excitation peaks between the Eu(III) coordination complexes based on TTA, PTA and NTA are in accord with the shift observed for $\pi-\pi^{*}{ }_{\beta}$-diketone electronic transition in transmittance spectra.

The room-temperature emission spectra of [Eu(TTA $\left.)_{3}(\mathrm{DPEPO})\right]$ in the solid state and embedded into EVA, PMMA and PVB are shown in Figure 3 (Figures S35-S54 for all complexes). Their spectra display the characteristic ${ }^{5} \mathrm{D}_{0} \rightarrow^{7} \mathrm{~F}_{0-4}$ transitions of $\mathrm{Eu}(\mathrm{III}):{ }^{5} \mathrm{D}_{0} \rightarrow{ }^{7} \mathrm{~F}_{0}(578 \pm 1 \mathrm{~nm}),{ }^{5} \mathrm{D}_{0} \rightarrow{ }^{7} \mathrm{~F}_{1}(591 \pm 2 \mathrm{~nm}),{ }^{5} \mathrm{D}_{0} \rightarrow{ }^{7} \mathrm{~F}_{2}$ $(612 \pm 1 \mathrm{~nm}),{ }^{5} \mathrm{D}_{0} \rightarrow{ }^{7} \mathrm{~F}_{3}(653 \pm 3 \mathrm{~nm})$ and ${ }^{5} \mathrm{D}_{0} \rightarrow{ }^{7} \mathrm{~F}_{4}(700 \pm 3$ $\mathrm{nm}) .^{23}$ The hypersensitive ${ }^{5} \mathrm{D}_{0} \rightarrow{ }^{7} \mathrm{~F}_{2}$ transition is very intense, reaching up to $80-90 \%$ of the total emission intensity and is responsible for the red-bright emission color. The unique ${ }^{5} \mathrm{D}_{0} \rightarrow{ }^{7} \mathrm{~F}_{0}$ transition peak centered at $578 \mathrm{~nm}$ indicates the presence of a single complex species in the solid state and in the polymers, and that the $\mathrm{Eu}^{3+}$ ion occupies a site with $C_{n v}, C_{n}$ or $C_{s}$ symmetry. ${ }^{23}$ Compounds $\mathbf{2}$ and $\mathbf{6}$, however, are characterized by a very weak ${ }^{5} \mathrm{D}_{0} \rightarrow^{7} \mathrm{~F}_{0}$ transition and by a well resolved two components ${ }^{5} D_{0} \rightarrow^{7} F_{1}$ transition in the solid state (Figures S37 and S45), which are typical feature for $D_{n}, C_{n h}, D_{n h}$, $D_{n d}, S_{n}$ symmetry groups. For these complexes the ${ }^{5} D_{0} \rightarrow^{7} F_{0}$ emission band increased after embedding into the polymer matrices, which clearly indicates the participation of the polymers in changing the structure by altering their symmetry. By analyzing the ${ }^{5} D_{0} \rightarrow{ }^{7} F_{2}$ emission band for all compounds, both in solid state and in polymers, we can reveal the compound $\mathbf{2}$ and $\mathbf{6}$ showed again some differences in the polymer matrices compared to solid state. However, their emission spectra in EVA, PMMA and PVB have no differences. In the case of other compounds no essential differences were observed between the emission spectra in the solid state and embedded into polymers. Using these emission data, the luminescence QYs were calculated within $10 \%$ absolute error and values are summarized in Table 1.

\section{(Table 1)}

The $\left[\mathrm{Eu}(\mathrm{TTA})_{3}(\mathrm{DBSO})_{2}\right]$ complex showed a decrease in $\mathrm{QY}$ when introduced in the polymer matrices which could be explained by a dissociation process occurring upon addition of the polymer. In the other cases, the complexes are more stable and the differences in $\mathrm{QY}$ are within experimental errors.

The PL lifetimes of the complexes 1-10 in the solid state and in EVA, PMMA and PVB polymer matrices were investigated by monitoring the emission at $613 \mathrm{~nm}$ upon excitation at $340 \mathrm{~nm}$ (Table 1). The decay curves were well fitted with monoexponential decay functions $\left(R^{2} \geq 98 \pm 1\right)$ suggesting the existence of a single species in the solid state as well as in the polymer matrices. The presence of the different possible isomers could explain the very small differences between the lifetimes. The lifetime of the europium(III) complexes in the solid state based on TTA increase in the following order of neutral ligand DBSO < TPPO < DPEPO < EPhen. The same trend is observed for PTA complexes and an almost opposite phenomenon is observed for NTA europium(III) complexes: EPhen $<$ TPPO $\approx$ DPEPO.

Introducing the complexes into EVA, PMMA and PVB polymer matrices affects the PL lifetimes. These phenomena might be explained by the interaction of the Eu(III) complexes with polymers, via oxygen donors, in order to form nine coordination complex and/or by dissociation reaction during the fabrication of $\mathrm{Eu}(\mathrm{III})$ doped polymer films. The largest effects on luminescence lifetime were observed for complex 3 from $0.90 \mathrm{~ms}$ in solid state to $0.54(3) \mathrm{ms}$ in polymers. In addition, the NTA based Eu(III) complexes showed an increase of PL lifetime when introduced in the polymers.

\section{CIGS Cells Characterization}

To evaluate the performance of the europium(III) complexes as downshifters for CIGS solar cells the compounds were embedded into EVA, PMMA and PVB polymer matrices and then deposited on the photovoltaic device. The EVA doped polymer films were deposited by lamination method and PMMA and PVB by drop casting. The complex concentrations were calculated to be around $0.3 \mathrm{wt} \%$ of Eu and the polymer thickness was around $0.1 \mathrm{~mm}$ for EVA and $0.05 \mathrm{~mm}$ for PMMA and PVB, respectively. These parameters were inspired from our previous work to ensure optimum EQE. ${ }^{18}$ 
The reflectance measurements of CIGS solar cells before and after encapsulation with EVA, PMMA and PVB polymers show a diminution of the reflectivity due to the different refractive index of polymers (1.50(5)) and ZnO:Al (2.0 at $400 \mathrm{~nm}) .{ }^{48}$ Using the Fresnel equations and refractive index data for $\mathrm{ZnO}: \mathrm{Al}$ and PMMA, we calculated the reflectance at the air/cell interface for different wavelengths (Figure 4).

\section{(Figure 4)}

The main source of reflectivity of CIGS solar cell is provided by the $\mathrm{ZnO}: \mathrm{Al}$ layer and it is important to note that the $\mathrm{Ni} / \mathrm{Al}$ grid contact reflectivity reaches up to $3.5 \%$. When the reflectance induced by ZnO:Al layer is cumulated with grid contacts reflectivity the total reflectivity becomes comparable to the experimental data. Once the cells are encapsulated with EVA, PMMA and PVB polymers the relative reflectivity drops by up to $30 \%$ due to different refractive index which enhance the cell efficiency in Vis and near IR region. In this case, the grid contact has a positive role as a mirror during the internal reflection, and enables to recover more photons. Other optical losses such as transmittance, scattering and diffraction induced by the LDS film are difficult to measure inside the cell and they are considered to be almost the same as on quartz substrate.

\section{Spectral response}

EQE measurements were performed on encapsulated CIGS solar cell with europium(III) complexes doped into EVA, PMMA and PVB polymers. As an example, spectra with $\left[\mathrm{Eu}(\mathrm{NTA})_{3}(\mathrm{DPEPO})\right](\mathbf{9})$ as a downshifter are shown in Figure 5 (see the Figures S56-65 for other complexes).

\section{(Figure 5)}

The EQE spectra of $\mathbf{9}$ shows a small EQE improvement in Vis and near IR region, which is mainly due to the decrease of the reflectivity. The same trend was also observed for all complexes embedded into EVA, PMMA and PVB. Approaching the UV region the LDS layer let to cross less and less high energy photons. They are absorbed and then converted into visible light. This downshifted energy light generates current which allows improving the solar cell efficiency in the UV region. However, as expected, marked changes are observed in the UV region (300 $\mathrm{nm}$ to $400 \mathrm{~nm}$ ) where the strong improvement of the spectral response (SR) proves the efficiency of this luminescent downshifter material. A similar phenomenon was observed in the case of all the other complexes embedded into EVA, PMMA and PVB. This is the result of four different contributions which can be calculated using Equation (1): ${ }^{49}$

$$
\eta_{E Q E}=(1-R) \cdot \eta_{I Q E} \cdot \eta_{a b s} \cdot \eta_{Q Y} \cdot \eta_{\text {trap }}
$$

where $\mathrm{R}$ is the reflectance at the air/cell interface, $\eta_{\text {IQE }}$ is the internal quantum efficiency (IQE) of solar cells at the emission wavelength of the compound, $\eta_{a b s}$ is the fraction of incident photons that are absorbed by emitting species, $\eta_{Q Y}$ is photoluminescence quantum yield of the complex in polymeric matrix, $\eta_{\text {trap }}$ is the luminescent trapping efficiency accounting for the reemission of photons towards the air.

Among these parameters, the easiest to estimate are the $R$ which is around $4 \%$ for the used polymers, ${ }^{50} \eta_{\text {IQE }}$ which is by $93 \pm 1 \%$ (from EQE of $84 \pm 1 \%$ (Figure 5 ) and reflectivity of 10 $\%$ (Figure 4) at $612 \mathrm{~nm}$ ), $\eta_{a b s}$ which is around $100 \%$ in the 330 $360 \mathrm{~nm}$ range for these complexes (transmittance spectra Figure S55) and $\eta_{Q Y}$ which can be taken from Table 1. A critical step is the evaluation of $\eta_{\text {trap }}$. By modifying the general formula of the trapping efficiency for a solar concentrator, and considering trapping losses only from the front face and neglected from the edge, and total absorption through the back face, ${ }^{51}$ Equation (2) is obtained:

$$
\eta_{\text {trap }}^{\text {iso }}=\frac{1}{2}+\frac{1}{2} \sqrt{1-\frac{n_{c}^{2}}{n_{s}^{2}}}
$$

where $n_{c}$ is the refractive index of the waveguide (here air $n_{c}=$ 1 ) and $n_{s}$ is the refractive index of cladding media (here the organic polymer).

This formula is valid for an isotropic emission and does not take into account optical losses such as scattering and diffraction induced by non-total solubility of the downshifter material into polymer matrix. Using the refractive index of air $\left(n_{c} \approx 1\right)$ and for example the one of PMMA at $613 \mathrm{~nm}\left(n_{s} \approx\right.$ 1.49) $\eta_{\text {trap }}$ is around $87 \%$. In the case of the complex 9 , the $\mathrm{EQE}^{330-360}$ calculated with $R \approx 4 \%, \eta_{\text {IQE }} \approx 93 \%, \eta_{\text {abs }} \approx 1, \eta_{\text {trap }} \approx$ 0.87 and $\eta_{Q Y}=0.78 \pm 0.10$, is $60 \pm 8 \%$ which is close to the experimental EQE at $360 \mathrm{~nm}$ of $58 \%$. As previously stated, there were no obvious differences in photo-physical properties between complexes embedded into EVA and PMMA or PVB, so that their SR performances were expected to be quite similar. Because of PMMA and PVB glassy properties, their deposition was made by procedure $B$ with more difficult quality control and thinner layer, which was sometimes reflected into differences of the EQE data between polymers.

The impact of downshifting on solar cell performance can be evaluated from short circuit current density $\left(\mathrm{J}_{\mathrm{sc}}\right)$ calculation from Equation (3).

$$
J_{s c}=q \int_{\lambda 0}^{\lambda 1} \Phi(\lambda) \cdot \operatorname{EQE}(\lambda) d \lambda
$$

where $q$ is the electron charge, $\lambda$ is the wavelength and $\Phi(\lambda)$ is the incident photon flux of the AM1.5G.

This formula was applied for the calculation of $J_{s c}$ contribution of the CIGS solar cells encapsulated with each Eu(III) complex doped EVA in the range of $300-400 \mathrm{~nm}$ and $300-420 \mathrm{~nm}$ (Figure 6). In the Figure 6 is represented the $J_{s c}$ values obtained from experimental EQE data and downshifting theoretical approach for the case of LDS ${ }^{\text {perfect }}$ and AM1.5G.

\section{(Figure 6)}

The $J_{s c}$ of AM1.5G considers perfect photon-electron generation of solar irradiance spectrum and for the case of an ideal LDS (LDS ${ }^{\text {perfect }}$ ) the following parameters were used: $R \approx 4$ $\%, \eta_{\text {IQE }} \approx 93 \%, \eta_{\text {abs }} \approx 1, \eta_{\text {trap }} \approx 0.87$ and $\eta_{Q Y}=1$. As a result the theoretical current density contribution of the sun and a perfect CIGS downshifter in the range of $300-400 \mathrm{~nm}$ is 1.35 
$\mathrm{mA} / \mathrm{cm}^{2}$ and, $1.09 \mathrm{~mA} / \mathrm{cm}^{2}$ respectively. The current density of CIGS solar cells in the $300-400 \mathrm{~nm}$ region is around 0.27 $\mathrm{mA} / \mathrm{cm}^{2}$ and this value can double and even triple once the cells are covered with different Eu(III) complexes doped EVA.

The downshifting complexes studied in this work enhance the current density of CIGS solar cells in the range of 300-400 nm from the minimum of $0.54 \mathrm{~mA} / \mathrm{cm}^{2}$ for 5 to the maximum of $0.77 \mathrm{~mA} / \mathrm{cm}^{2}$ for 2. This represents $40-56 \%$ of AM1.5G sunlight $\mathrm{J}_{\mathrm{sc}}$ and $50-71 \%$ of a perfect LDS $\mathrm{J}_{\mathrm{sc}}$. The most efficient complex in this series is $\mathbf{2}$, leading to an EQE improvement in UV region up to 2.8 times compared to CIGS alone. Very similar performances were measured for $\left(\left[\mathrm{Eu}(\mathrm{TTA})_{3}(\mathrm{TPPO})_{2}\right]\right)$ (0) ${ }^{18}$ as expected from their similar optical properties, and in particular from the QYs obtained from PL measurements (70\% for 0 in EVA and $78 \%$ for 2). Unfortunately, compounds 3, 4, 8, $\mathbf{9}$ and $\mathbf{1 0}$ led to similar EQE efficiencies despite their improved QYs. In particular, it is to be noticed that the complex

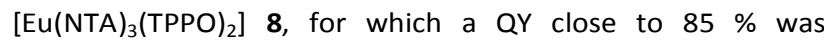
measured in EVA, did not give improved EQE properties.

\section{I-V Measurements}

The I-V characteristics of CIGS solar cells encapsulated with the europium(III) complexes 1-10 embedded into EVA, PMMA and PVB were measured under standard solar illumination (AM1.5G). The LDS deposited on CIGS caused an increase of $J_{s c}$ without significant changes in open circuit voltage $\left(\mathrm{V}_{\text {oc }}\right)$ and fill factors (FF) (Figure 7).

\section{(Figure 7)}

The improvements in current density correspond to the sum of downshifting contribution, only in the $300-400 \mathrm{~nm}$ region and antireflection effect within the 300-1200 $\mathrm{nm}$ range. These measurements make difficult to estimate the real impact of downshifting. The most representative evaluation is the spectral response measurement that enables to estimate the $\mathrm{J}_{\mathrm{sc}}$ improvement and by consequence the solar cell conversion efficiency via Equation (4).

$$
\eta=\frac{V_{o c} \cdot J_{s c} \cdot F F}{P_{\text {solar }}}
$$

where $P_{\text {solar }}$ is $1000 \mathrm{~W} / \mathrm{m}^{2}, J_{s c}$ is calculated from EQE data and $V_{o c}$ and $F F$ are taken from I-V measurements.

Considering the data of calculated $J_{s c}^{300-400 \mathrm{~nm}}$ in this way, $\Delta J_{s c}^{300-400 \mathrm{~nm}}$ is extracted from $\Delta \mathrm{J}_{s c}^{300-400 \mathrm{~nm}}=\mathrm{J}_{s c}^{300-400 \mathrm{~nm}}$ (CIGS+LDS) - $J_{s c}^{300-400 \mathrm{~nm}}$ (CIGS) and gives $0.27-0.50 \mathrm{~mA} / \mathrm{cm}^{2}$. The CIGS solar cells used for this study have $\mathrm{V}_{\mathrm{oc}}=0.645(5) \mathrm{mV}$ and $\mathrm{FF}=0.70(1)$, so that the downshifting contribution on conversion efficiency $(\Delta \eta)$ is in the range of 0.12-0.23\%.

As mentioned above, the $\mathrm{J}_{\mathrm{sc}}{ }^{300-1200 \mathrm{~nm}}$ (CIGS+LDS) is the sum of downshifting and optical phenomena, and the latter strongly depends on polymer deposition quality which is more difficult to control. The $\Delta \mathrm{J}_{\mathrm{sc}}$ calculated from EQE $\mathrm{EQ0}^{300-1200 \mathrm{~nm}}$ data and the one obtained from I-V measurements are comparable within the limits of error and, in the best case it reaches $1.8 \mathrm{~mA} / \mathrm{cm}^{2}$, or in terms of conversion efficiency, $0.8 \%$ absolute.

\section{Conclusions}

In this work eight novel out of ten Eu(III) complexes with the general formula $\left[\mathrm{Eu}(\beta \text {-Diketonate })_{3}(\text { Neutral Ligand })_{1-2}\right.$ ] have been designed, synthesized by one-pot reaction and characterized by elemental analysis, FT-IR, ${ }^{1} \mathrm{H},{ }^{13} \mathrm{C}$ and ${ }^{19} \mathrm{~F}$ NMR and photoluminescence spectroscopy. The design of new europium(III) $\beta$-diketonate were aimed to provide efficient downconverters with $\mathrm{QY}$ approaching unity for $\mathrm{CIGS}$ solar cells or other similar photovoltaic devices. These compounds showed an efficient energy transfer from ligand to europium(III) with final QYs in the 55-83 $\pm 10 \%$ range in the solid state and $34-86 \pm 10 \%$ after doping into different polymers. The spectral response measurements of $\mathrm{CIGS}$ solar cells encapsulated with Eu(III) complexes doped EVA, PMMA and PVB revealed an improvement of EQE by up to $58 \%$ at 360 $\mathrm{nm}$ for the best compound. The EQE enhancement for each compound matches well with our predictions where the $Q Y$ plays a crucial role. The calculated $\mathrm{J}_{\mathrm{sc}}$ in the $300-400 \mathrm{~nm}$ range showed an improvement from $0.27 \mathrm{~mA} / \mathrm{cm}^{2}$ for a nonencapsulated CIGS cell to $0.54 \mathrm{~mA} / \mathrm{cm}^{2}$ for the less efficient downshifter and up to $0.77 \mathrm{~mA} / \mathrm{cm}^{2}$ for the best LDS obtained experimentally. This represents $56 \%$ of maximum photonelectron generation from solar spectrum and $71 \%$ of an ideal downshifter. I-V measurements of the best LDS encapsulated CIGS cells showed an absolute increase of $0.8 \%$ of conversion efficiency induced both by LDS contribution (up to $0.23 \%$ ) and by antireflection effect of the polymers. While the developed materials were applied to CIGS solar cells, similar applications can be envisaged for other types of solar cells, in particular organic, hybrid and hybrid perovskite solar cells in which exposure to UV can be detrimental. In this case, the enhanced encapsulant provides UV protection for the polymer and the solar cells and recovery of this energy for conversion into extra electrons. The downshifting concept falls within the ShockleyQueisser limit, but doubled EQEs and above Shockley-Queisser conditions could be obtained thanks to downconversion, although substantial progress in such materials are required beforehand.

\section{Acknowledgements}

This work was carried out in the framework of a project of IPVF (Institut Photovoltaïque d'lle-de-France). This project has been supported by the French Government in the frame of the program of investment for the future (Programme d'Investissement d'Avenir - ANR-IEED-002-01). The authors are grateful to M. Paire, C. Crevant, F. Donsanti, M. Jubault, L. Michely and S. Rives for fabrication of CIGS solar cells.

\section{References}

1 R. B. Wehrspohn, U. Rau and A. Gombert, Eds., Photon management in solar cells, Wiley-VCH, Weinheim, 2015.

2 A. Martí and A. Luque, Eds., Next generation photovoltaics: high efficiency through full spectrum utilization, Institute of Physics, Bristol, 2004. 
3 H. Lian, Z. Hou, M. Shang, D. Geng, Y. Zhang and J. Lin, Energy, 2013, 57, 270-283.

4 X. Huang, S. Han, W. Huang and X. Liu, Chem Soc Rev, 2013, 42, 173-201.

5 M. A. Green, Third generation photovoltaics: advanced solar energy conversion, Springer, Berlin, Soft-cover ed., 2006.

6 D. Chen, Y. Wang and M. Hong, Nano Energy, 2012, 1, 7390.

7 K. Grzeszkiewicz, L. Marciniak, W. Stręk and D. Hreniak, J. Lumin., 2016, 177, 172-177.

8 J.-C. G. Bünzli and V. K. Pecharsky, Eds., Handbook on the physics and chemistry of rare earths:: including actinides. Vol. 44: [...], Elsevier, North Holland, Amsterdam, 2014.

9 S. D. Hodgson, W. S. M. Brooks, A. J. Clayton, G. Kartopu, V. Barrioz and S. J. C. Irvine, Nano Energy, 2014, 4, 1-6.

10 S. Kalytchuk, S. Gupta, O. Zhovtiuk, A. Vaneski, S. V. Kershaw, H. Fu, Z. Fan, E. C. H. Kwok, C.-F. Wang, W. Y. Teoh and A. L. Rogach, J. Phys. Chem. C, 2014, 118, 16393-16400.

11 G. Shao, C. Lou, J. Kang and H. Zhang, Appl. Phys. Lett., 2015, 107, 253904.

12 M. Jalalah, Y.-H. Ko, F. A. Harraz, M. S. Al-Assiri and J.-G. Park, Nano Energy, 2017, 33, 257-265.

13 K. Bouras, G. Schmerber, D. Aureau, H. Rinnert, G. Ferblantier, T. Fix, S. Colis, P. Bazylewski, B. Leedahl, A. Etcheberry, G. S. Chang, A. Dinia and A. Slaoui, RSC Adv, 2016, 6, 67157-67165.

14 M. Nam, H.-K. Kwon, S. J. Kwon, S.-H. Kwon, M. Cha, S.-H. Lee, S. Park, D. Jeong, K.-T. Lee, H. Rhee, Y. R. Do, S. Kim, K. Kim, R. H. Friend, J. S. Han, I. K. Han and D.-H. Ko, Adv. Energy Mater., 2016, 6, 1502404.

15 E. Klampaftis and B. S. Richards, Prog. Photovolt. Res. Appl., 2011, 19, 345-351.

16 D. Alonso-Álvarez, D. Ross, E. Klampaftis, K. R. Mclntosh, S. Jia, P. Storiz, T. Stolz and B. S. Richards, Prog. Photovolt. Res. Appl., 2015, 23, 479-497.

17 T. Uekert, A. Solodovnyk, S. Ponomarenko, A. Osvet, I. Levchuk, J. Gast, M. Batentschuk, K. Forberich, E. Stern, H.-J. Egelhaaf and C. J. Brabec, Sol. Energy Mater. Sol. Cells, 2016, 155, 1-8.

18 A. Gavriluta, T. Fix, A. Nonat, M. Paire, A. Slaoui, L. J. Charbonnière and J.-F. Guillemoles, Adv. Opt. Mater., 2016, 4, 1846-1853.

19 T. Fix, A. Nonat, D. Imbert, S. Di Pietro, M. Mazzanti, A. Slaoui and L. J. Charbonnière, Prog. Photovolt. Res. Appl., 2016, 24, 1251-1260.

20 T. Monzón-Hierro, J. Sanchiz, S. González-Pérez, B. González-Díaz, S. Holinski, D. Borchert, C. HernándezRodríguez and R. Guerrero-Lemus, Sol. Energy Mater. Sol. Cells, 2015, 136, 187-192.

21 G. Griffini, F. Bella, F. Nisic, C. Dragonetti, D. Roberto, M. Levi, R. Bongiovanni and S. Turri, Adv. Energy Mater., 2015, 5, 1401312.

22 J. Liu, K. Wang, W. Zheng, W. Huang, C.-H. Li and X.-Z. You, Prog. Photovolt. Res. Appl., 2012, 21, 668-675.

23 K. Binnemans, Coord. Chem. Rev., 2015, 295, 1-45.

24 H. Xu, Q. Sun, Z. An, Y. Wei and X. Liu, Coord. Chem. Rev., 2015, 293-294, 228-249.
25 S. V. Eliseeva, O. V. Kotova, F. Gumy, S. N. Semenov, V. G. Kessler, L. S. Lepnev, J.-C. G. Bünzli and N. P. Kuzmina, J. Phys. Chem. A, 2008, 112, 3614-3626.

26 R. Pavithran, M. L. P. Reddy, S. A. Junior, R. O. Freire, G. B. Rocha and P. P. Lima, Eur. J. Inorg. Chem., 2005, 2005, 41294137.

27 Y. Zhang, H. Shi, Y. Ke and Y. Cao, J. Lumin., 2007, 124, 5157.

28 S. Biju, R. O. Freire, Y. K. Eom, R. Scopelliti, J.-C. G. Bünzli and H. K. Kim, Inorg. Chem., 2014, 53, 8407-8417.

29 M. Räsänen, H. Takalo, J. Rosenberg, J. Mäkelä, K. Haapakka and J. Kankare, J. Lumin., 2014, 146, 211-217.

30 Y. Ma and Y. Wang, Coord. Chem. Rev., 2010, 254, 972990.

31 J.-C. G. Bünzli, Coord. Chem. Rev., 2015, 293-294, 19-47.

32 M. M. Nolasco, P. M. Vaz, V. T. Freitas, P. P. Lima, P. S. André, R. A. S. Ferreira, P. D. Vaz, P. Ribeiro-Claro and L. D. Carlos, J. Mater. Chem. A, 2013, 1, 7339.

33 E. E. S. Teotonio, G. M. Fett, H. F. Brito, W. M. Faustino, G. F. de Sá, M. C. F. C. Felinto and R. H. A. Santos, J. Lumin., 2008, 128, 190-198.

34 H. Xu, L.-H. Wang, X.-H. Zhu, K. Yin, G.-Y. Zhong, X.-Y. Hou and W. Huang, J. Phys. Chem. B, 2006, 110, 3023-3029.

35 O. L. Malta, H. F. Brito, J. F. S. Menezes, F. R. G. e Silva, S. Alves, F. S. Farias and A. V. M. de Andrade, J. Lumin., 1997, 75, 255-268.

36 O. L. Malta, H. F. Brito, J. F. S. Menezes, F. R. Gonçalves e Silva, C. de Mello Donegá and S. Alves, Chem. Phys. Lett., 1998, 282, 233-238.

37 L. D. Carlos, C. De Mello Donegá, R. Q. Albuquerque, S. Alves, J. F. S. Menezes and O. L. Malta, Mol. Phys., 2003, 101, 1037-1045.

38 G. R. Fulmer, A. J. M. Miller, N. H. Sherden, H. E. Gottlieb, A. Nudelman, B. M. Stoltz, J. E. Bercaw and K. I. Goldberg, Organometallics, 2010, 29, 2176-2179.

39 T. Klinkert, M. Jubault, F. Donsanti, D. Lincot and J.-F. Guillemoles, J. Renew. Sustain. Energy, 2014, 6, 011403.

40 T. Klinkert, M. Jubault, F. Donsanti, D. Lincot and J.-F. Guillemoles, Thin Solid Films, 2014, 558, 47-53.

41 S. Sato and M. Wada, Bull. Chem. Soc. Jpn., 1970, 43, 19551962.

42 H. Xin, M. Shi, X. C. Gao, Y. Y. Huang, Z. L. Gong, D. B. Nie, H. Cao, Z. Q. Bian, F. Y. Li and C. H. Huang, J. Phys. Chem. B, 2004, 108, 10796-10800.

43 M. Congiu, M. Alamiry, O. Moudam, S. Ciorba, P. R. Richardson, L. Maron, A. C. Jones, B. S. Richards and N. Robertson, Dalton Trans., 2013, 42, 13537.

44 L. R. Melby, N. J. Rose, E. Abramson and J. C. Caris, J. Am. Chem. Soc., 1964, 86, 5117-5125.

$45 \mathrm{~K}$. Nakamoto and K. Nakamoto, Applications in coordination, organometallic, and bioinorganic chemistry, Wiley, Hoboken, N.J, 6. ed., 2009.

46 L. Di Bari and P. Salvadori, Coord. Chem. Rev., 2005, 249, 2854-2879.

47 P. Kadjane, L. Charbonnière, F. Camerel, P. P. Lainé and R. Ziessel, J. Fluoresc., 2008, 18, 119-129.

48 M. N. Polyanskiy, Refractivelndex.INFO, 2013. 
49 A. Goetzberger and W. Greube, Appl. Phys., 1977, 14, 123139.

50 M. G. Debije and P. P. C. Verbunt, Adv. Energy Mater., 2012, 2, 12-35.

\section{Graphs and tables}

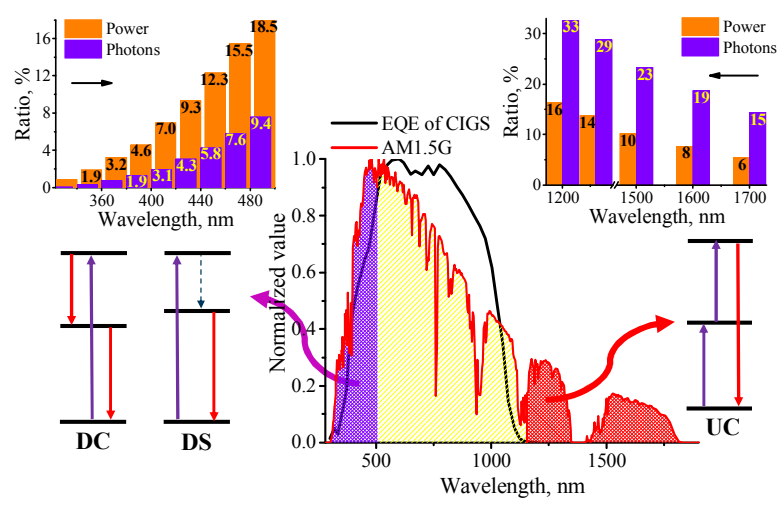

Figure 1. Normalized Air-Mass $1.5 \mathrm{G}\left(\mathrm{AM}\right.$ 1.5G, W. $\left.\mathrm{m}^{-2} \cdot \mathrm{nm}^{-1}\right)$ solar irradiance spectrum with external quantum efficiency (EQE) of CIGS solar cells used in this work. Schematic representation of the mechanism of downshifting (DS), downconversion (DC) and upconversion (UC). Calculated power and photon percentages of the AM 1.5 in the range of $280-500 \mathrm{~nm}$ available for DS and DC (on the left) and in the $4000-1200 \mathrm{~nm}$ region available for UC (on the right).

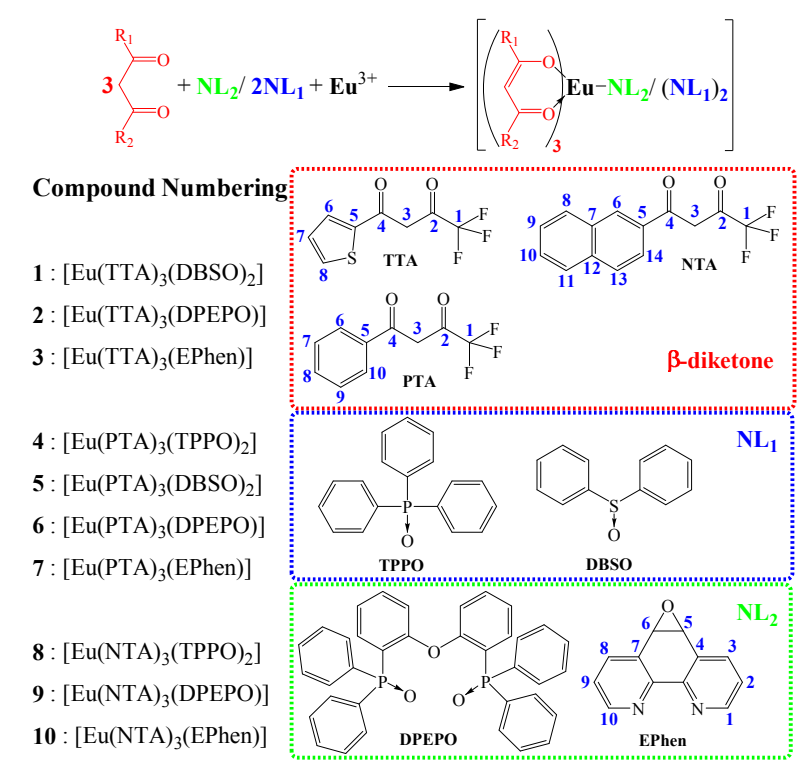

Figure 2. General synthetic pathway of $\mathrm{Eu}(\mathrm{III})$ coordination complexes synthesis and $\mathrm{C}$ numbering of the ligands.
51 C. L. Mulder, P. D. Reusswig, A. M. Velázquez, H. Kim, C. Rotschild and M. A. Baldo, Opt. Express, 2010, 18, A79. 


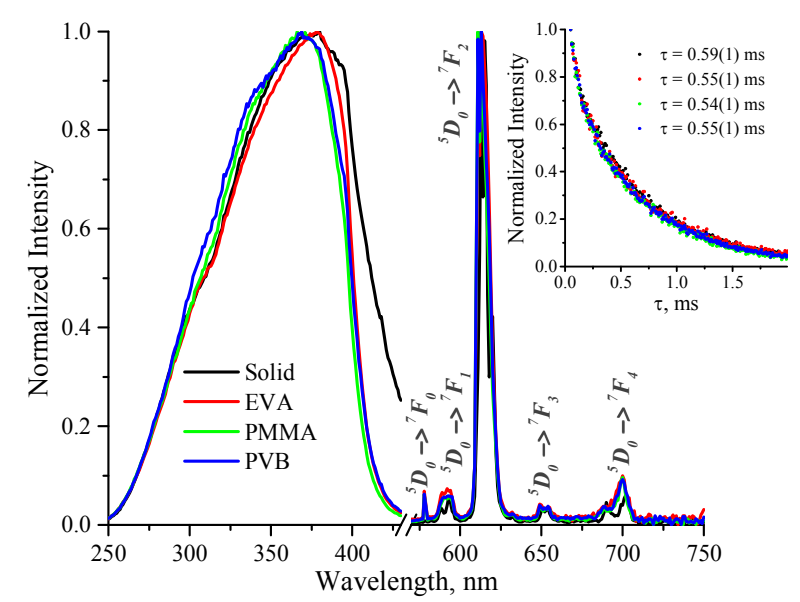

Figure 3. Excitation $\left(\lambda_{\mathrm{em}}=613 \mathrm{~nm}\right)$, emission $\left(\lambda_{\mathrm{ex}}=340 \mathrm{~nm}\right)$ and PL decay (inset, $\lambda_{\mathrm{ex}}$ $\left.=340 \mathrm{~nm}, \lambda_{\mathrm{em}}=613 \mathrm{~nm}\right)$ spectra of $\left[\mathrm{Eu}(\text { TTA })_{3}(\mathrm{DPEPO})\right]$ in the solid state and embedded into EVA, PMMA and PVB.

Table 1. Luminescence QY and lifetimes of Eu(III) coordination complexes in the solid state and in EVA, PMMA and PVB matrices $\left(\lambda_{\text {ex }}=340 \mathrm{~nm}\right)$.

\begin{tabular}{|c|c|c|c|c|c|c|}
\hline Complex & parameter & literature & solid & EVA & PMMA & PVB \\
\hline$\left[\mathrm{Eu}(\mathrm{TTA})_{3}(\mathrm{DBSO})_{2}\right]$ & $\Phi(\%)$ & $85^{36}$ & 81 & 36 & 48 & 34 \\
\hline 1 & $\tau(\mathrm{ms})$ & $0.714^{36}$ & $0.38(1)$ & $0.34(1)$ & $0.45(1)$ & $0.33(1)$ \\
\hline$\left[\mathrm{Eu}(\mathrm{TTA})_{3}(\mathrm{DPEPO})\right]$ & $\Phi(\%)$ & n.a & 82 & 78 & 74 & 75 \\
\hline 2 & $\tau(\mathrm{ms})$ & n.a & $0.59(1)$ & $0.55(1)$ & $0.54(1)$ & $0.55(1)$ \\
\hline$\left[\mathrm{Eu}(\mathrm{TTA})_{3}(\right.$ EPhen $\left.)\right]$ & $\Phi(\%)$ & $82(8)$ & 78 & 79 & 71 & 70 \\
\hline 3 & $\tau(\mathrm{ms})$ & $0.806(5)^{32}$ & $0.90(1)$ & $0.57(2)$ & $0.51(1)$ & $0.54(1)$ \\
\hline$\left[\mathrm{Eu}(\mathrm{PTA})_{3}(\mathrm{TPPO})_{2}\right]$ & $\Phi(\%)$ & n.a & 76 & 80 & 83 & 79 \\
\hline 4 & $\tau(\mathrm{ms})$ & n.a & $0.52(1)$ & $0.53(1)$ & $0.56(1)$ & $0.50(1)$ \\
\hline$\left[\mathrm{Eu}(\mathrm{PTA})_{3}(\mathrm{DBSO})_{2}\right]$ & $\Phi(\%)$ & n.a & 57 & 47 & 54 & 48 \\
\hline 5 & $\tau(\mathrm{ms})$ & n.a & $0.43(1)$ & $0.45(2)$ & $0.49(3)$ & $0.40(3)$ \\
\hline$\left[\mathrm{Eu}(\mathrm{PTA})_{3}(\mathrm{DPEPO})\right]$ & $\Phi(\%)$ & n.a & 69 & 58 & 68 & 60 \\
\hline 6 & $\tau(\mathrm{ms})$ & n.a & $0.68(1)$ & $0.55(1)$ & $0.58(1)$ & $0.56(1)$ \\
\hline$\left[\mathrm{Eu}(\mathrm{PTA})_{3}(\mathrm{EPhen})\right]$ & $\Phi(\%)$ & n.a & 55 & 56 & 48 & 48 \\
\hline 7 & $\tau(\mathrm{ms})$ & n.a & $0.71(1)$ & $0.74(1)$ & $0.61(1)$ & $0.67(1)$ \\
\hline$\left[\mathrm{Eu}(\mathrm{NTA})_{3}(\mathrm{TPPO})_{2}\right]$ & $\Phi(\%)$ & n.a & 83 & 85 & 86 & 71 \\
\hline 8 & $\tau(\mathrm{ms})$ & n.a & $0.44(2)$ & $0.64(2)$ & $0.63(2)$ & $0.55(3)$ \\
\hline$\left[\mathrm{Eu}(\mathrm{NTA})_{3}(\mathrm{DPEPO})\right]$ & $\Phi(\%)$ & n.a & 82 & 80 & 82 & 79 \\
\hline 9 & $\tau(\mathrm{ms})$ & n.a & $0.45(1)$ & $0.51(1)$ & $0.53(1)$ & $0.50(1)$ \\
\hline$\left[\mathrm{Eu}(\mathrm{NTA})_{3}(\mathrm{EPhen})\right]$ & $\Phi(\%)$ & n.a & 76 & 81 & 80 & 75 \\
\hline 10 & $\tau(\mathrm{ms})$ & n.a & $0.32(2)$ & $0.49(1)$ & $0.47(1)$ & $0.56(2)$ \\
\hline
\end{tabular}




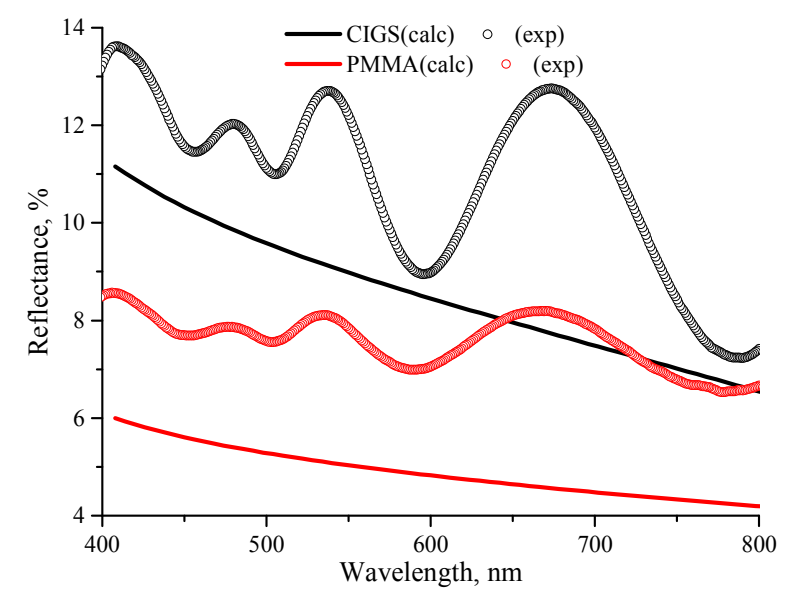

Figure 4. Measured (circle line) and calculated (straight line) reflectance spectra of CIGS and PMMA encapsulated solar cell without taking into account the interference and contact shading.

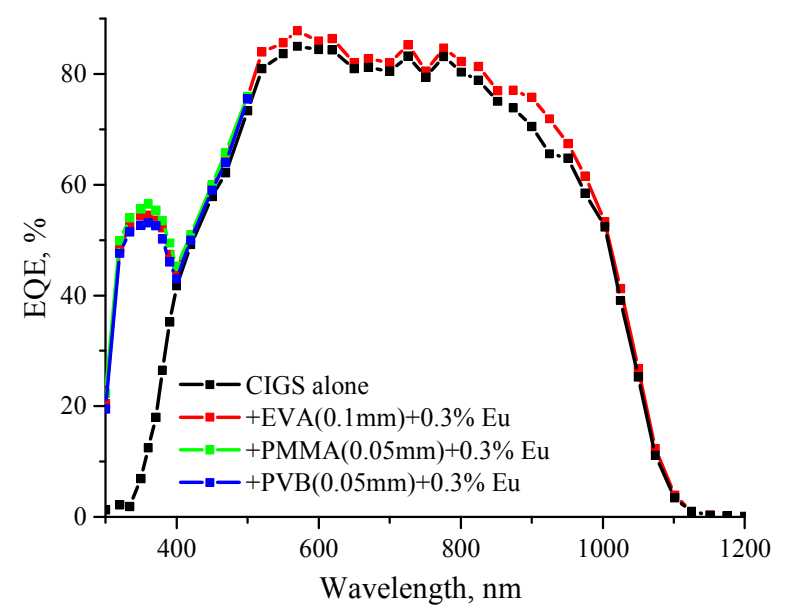

Figure 5. EQE spectra of CIGS solar cells encapsulated by different polymers doped with $\left[\mathrm{Eu}(\mathrm{NTA})_{3}(\mathrm{DPEPO})\right]$. The curves of PMMA and PVB were not represented in the Vis and NIR region for clarity. 


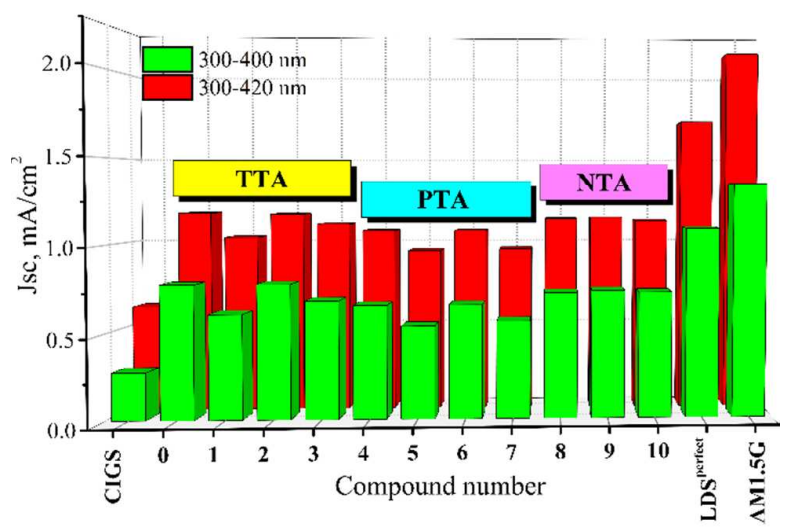

Figure 6. Calculated $\mathrm{J}_{\mathrm{sc}}$ values for $300-400 \mathrm{~nm}$ (green) and $300-420 \mathrm{~nm}$ (red) regions by using the Equation (3) and EQE spectra of CIGS solar cells encapsulated with Eu(III) complex doped EVA.

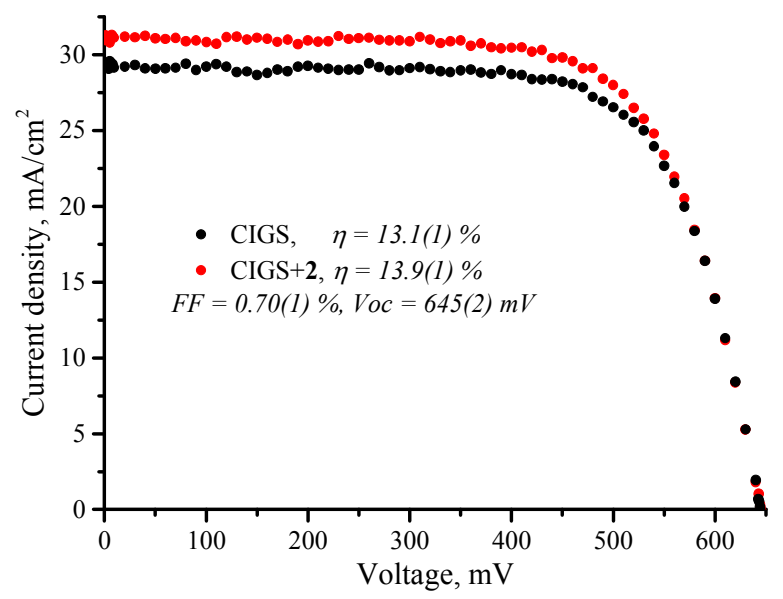

Figure 7. I-V characteristic for encapsulated and non-encapsulated CIGS solar cells with the complex 2 embedded into EVA. 
New highly luminescent europium(III) complexes are designed, synthesized, comprehensively characterized and successfully tested as photon downshifter for CIGS solar cells.

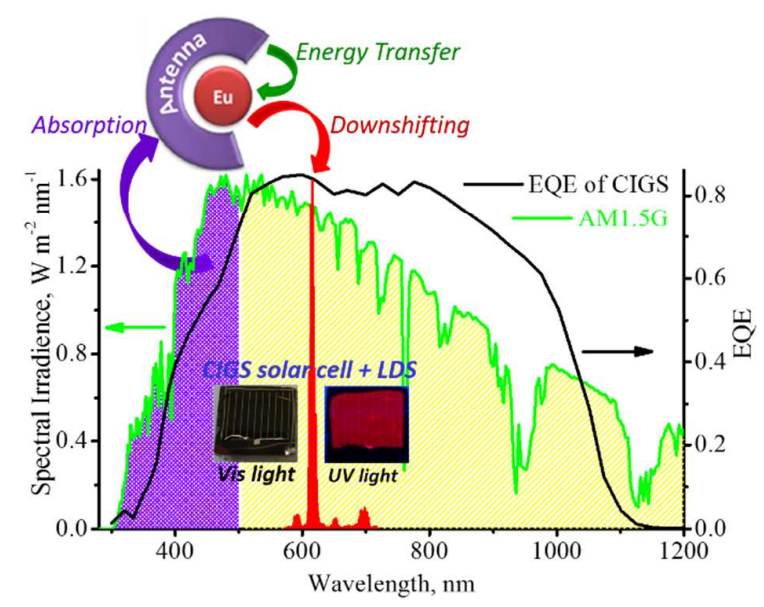

